Article

\title{
The Use of Bibliotherapy in Revealing and Addressing the Spiritual Needs of Cancer Patients
}

\author{
Ágnes Bálint ${ }^{1, *}$ and Judit Magyari ${ }^{2}$ \\ 1 Doctoral School of Reformed Theology, Debrecen Reformed Theological University, 4026 Debrecen, Hungary \\ 2 Onco-radiology Clinic, Clinical Center, University of Debrecen, 4032 Debrecen, Hungary; \\ magyari.judit@med.unideb.hu \\ * Correspondence: balint.agnes@silver.drk.hu
}

Received: 13 February 2020; Accepted: 11 March 2020; Published: 14 March 2020

check for updates

\begin{abstract}
Assessing and addressing spiritual needs is a key factor in the quality of life and overall wellbeing of cancer patients. However, the evolution and diversification of assessment tools has not automatically been followed by their successful implementation; thus, addressing unmet needs continues to be a concern. In this paper, we examine the place of bibliotherapy (also called reading therapy or poetry therapy) as a group intervention in the oncological setting in revealing spiritual needs. We show that it represents not only a useful intervention but may also provide instant relief and reduce spiritual suffering. Bibliotherapy understood and practiced as a subtle balance of texts and group processes alleviates cognitive and emotional symptoms of a spiritual concern and facilitates finding meaning in life in general and illness in particular. As an intervention, it is effective, affordable and attractive; moreover, it equips patients receiving treatment and rehabilitation with the lifelong skill of reflective reading. Bibliotherapy is easily tailored to almost any needs and promotes self-expression, which provides spiritual fulfillment in itself.
\end{abstract}

Keywords: spiritual needs; nonterminal cancer patients; interactive bibliotherapy; creative bibliotherapy; group psychotherapy

\section{Introduction}

Considerable empirical evidence is already available to support the idea that spirituality and religion share a positive correlation with mental health in general, and indirectly provide benefits for physical health as well (Moreira-Almeida et al. 2014; Seybold and Hill 2001). Studies have found correlations between individual variables, and special attention has been paid to the exact mechanisms of how spirituality and religion affect health: they give rise to better adjustment, well-being, quality of life through social support, meaning-making, reduction of self-focus and worry, emotion regulation, etc. (Garssen et al. 2014; Riley et al. 1998). While there is still much experiential observation to be scientifically validated, earlier findings have already suggested that spiritual care is an important part of health care and should be integrated into clinical practice (Wills 2007).

Spirituality and religion are multidimensional, connected and overlapping concepts. From a religious perspective, all religions and religious traditions have their own specific spirituality, a combination of distinguishing values, concepts and practices (McGrath 1999). In spite of a decrease in the number of religious affiliations, these values, concepts and practices may outlast and subsist irrespective of their original context. Meditation, for instance, is intrinsically connected to more distinct religious traditions; nevertheless, it is maintained as a secular practice as well exhibiting measurable health gains (Wachholtz and Pargament 2005). The simultaneous presence of different religious traditions in society may form a blend of beliefs that eventuates unique personal religiosities; thus, care providers face growing diversity and complexity regarding spirituality (Walsh 2010). 
From a psychological perspective, concepts of spirituality aim at capturing what is universal in human beings. Jungian analytic psychology and transpersonal psychology serve as a theoretical background for these concepts. Piedmont's Big Five model of personality is completed with the sixth component of spirituality, representing an additional level of personality development beyond the self that encompasses values such as altruism, humanity, quest for meaning, and responsibility (not only for the self, but also for the other or the universe). Humanistic spirituality, as opposed to religious spirituality, is neither God-centered nor attached to religious institutions.

Harold Koenig refers to this expansion of the concept of spirituality with constructs of positive psychology, personal wellbeing and mental health as a "contaminated" understanding of spirituality and draws attention to the tautology of results in measuring spirituality in a research context. However, he also acknowledges that his call for clear, distinct, non-overlapping definitions of spirituality (and mental and physical health) are not applicable in a clinical setting. On the contrary, an inclusive understanding of spirituality is to be used to facilitate communication and the assessment of needs without the discrimination or exclusion of patients (Koenig 2008). In turn, clinical experience may fuel further theorizing input for research.

In the complex relationship of spirituality/religion and health, spiritual or religious issues might not only play a role in the healing process but may also represent a health risk (controlling religious beliefs and communities, or beliefs causing anxiety, low self-esteem, inability to live up to expectations, etc.). Josephson identifies strategies for clinical symptoms which have a spiritual or religious etiologic component and emphasizes the idea that all case formulations have to evaluate a mosaic of protection factors and risk factors concerning all aspects of the bio-psycho-socio-spiritual model of illness and healing. This evaluation serves as a basis for a decision regarding how to address a spiritual or religious issue, if not transferring this to another authority (Josephson 2004).

Due to efforts made for the inclusion of the spiritual perspective in clinical care, several assessment tools have been developed and tested to obtain a spiritual history of patients and meet their needs (Best et al. 2020; de Jager Meezenbroek et al. 2012a). For the purposes of this paper, we use the definition of spirituality by de Jager Meezenbroek et al., which has been in use for the development of the spiritual assessment tool SAIL (Spiritual Attitude and Involvement List) (de Jager Meezenbroek et al. 2012b). In spite of recommendations and the evolution of assessment tools, their application is still not without difficulties. Care givers have to find the most suitable team members, timing and methods to assess and address spiritual needs in order to provide holistic care and take advantage of all healing potentials for the benefit of patients. Although testing has produced promising results in patient acceptance, time efficiency of assessment, etc., the main concerns of professional boundaries, role insecurity, professional knowledge of the field of spirituality and religion are still pertinent. Moreover, the spiritual beliefs, needs and states of patients vary during treatment or following major changes in their course of disease, which would call for a repeated assessment of needs.

Unfortunately, the global epidemiological cancer burden is continuously increasing. Within Europe, Hungary has one of the highest cancer-related overall mortality rates in men (estimated age-standardized rates (ASRs): 306.3 in Hungary vs. 222.5 in Europe) and the third highest mortality among women (163.6 vs. 128.8 in Europe) (Menyhárt et al. 2018). These indicators of cancer morbidity and mortality have not improved significantly since the turn of the millennium (Mailáth et al. 2017). Similarly, the availability and territorial distribution of multidisciplinary professional teams (including several medical practitioners such as surgeons, pathologists, oncologists, and registered nurses, physical therapists, onco-psychologists, psychiatrists, mental health professionals, hospital pastors, social workers and trained volunteers) are far from satisfactory; for instance, only large medical centers are equipped with onco-psychologic teams (Mailáth et al. 2017; Horti and Riskó 2006).

To improve the efficiency of onco-psychologic teams, the adaptation and wide introduction of an assessment tool for identifying patient needs has begun, namely by compiling the Hungarian standards for the Distress Thermometer and the Problem List as a first step of a complex program to create a general psycho-oncologic screening (Mailáth et al. 2017). However, among the 40 items on the Problem 
List, only one refers to religious/spiritual needs. Concurrently, differentiated lists and interpretations of needs are already available in the literature regarding the spiritual needs of various patient populations, including cancer patients (Büssing and Koenig 2010; Lazenby 2018; Surbone and Baider 2010).

The purpose of this paper is to evaluate whether bibliotherapy as an intervention is able to reveal the spiritual needs of cancer patients undergoing treatment and rehabilitation. We present our findings of three interventions in a clinical setting based on the minutes and written feedback of participants, which are organized and conceptualized according to the spiritual assessment tool of SAIL (Spiritual Attitude and Involvement List). As our bibliotherapeutic intervention took place in the clinical setting, spirituality is understood inclusively, according to the definition of SAIL: "one's striving for and experience of connection with the essence of life" (de Jager Meezenbroek et al. 2012b).

We have to note that bibliotherapy is considered to be an intervention used in different clinical and educational settings for a large number of purposes (Fanner and Urquhart 2008; Gualano et al. 2017; Popa and Porumbu 2017; Montgomery and Maunders 2015; Gregory and Vessey 2004; Maich and Kean 2004). Based on our empirical evidence, we argue that it is also able to reveal and address the spiritual needs of cancer patients. As opposed to more well developed and standardized assessment tools, it presents an opportunity with a number of advantages (such as the identification of needs not yet made conscious, identification of needs over a longer period of time, potentiality of an instant addressing available at identification, etc.) and some disadvantages (such as being time consuming, less systematic, prone to being accidental, etc.)

\section{Data and Methods}

\subsection{Theoretical Concepts}

In its most inclusive understanding, bibliotherapy is an intervention based on the use of any literature to support mental well-being (Bibliotherapy 2016). In interactive bibliotherapy, a trained facilitator uses guided discussions to help the clinical or developmental participant(s) integrate both feelings and cognitive responses to a selected work of literature, which may be a printed text, some form of audio-visual material, or creative writing by the participant (McCarty Hynes and Hynes-Berry 2012). This definition characterizes the bibliotherapeutic intervention as a form of socio-therapy and as a specific branch of art therapy, where art is reduced to the creative usage of language and literary forms.

Arlene McCarthy Hynes also describes the bibliotherapeutic process in detail and claims it is a series of recognition, examination, juxtaposition of feelings and ideas culminating with an application to the self. The four steps in catalyzing behavioral and emotional change are the following: 1 , recognition - a feeling of being touched intellectually, or emotionally, or engaged in any other way by the text; 2, examination-a deliberate intellectual act of thinking through, scrutinizing, understanding the experience recognized - that is, a kind of look behind the primary experience; 3 , juxtaposition-the comparison and contrast of the primary experience with the examined experience, or the reflection of others in the group if it has been shared; and 4, application to the self-after evaluation, a new level of recognition and understanding comes into being, and this insight has to be integrated into an effective bibliotherapeutic process. (McCarty Hynes and Hynes-Berry 2012)

Contrary to the use of any kind of literature, we preferred a narrower understanding of bibliotherapy, sometimes referred to as creative bibliotherapy, which limits the choice of literature to fictional works or poetry and relies equally on group processes. We delimit our practice from prescriptive bibliotherapy, which is built on self-help books and applies either cognitive or behavioral therapy (Gualano et al. 2017). While self-help therapies are treatments that require minimal contact with the therapist, interactive bibliotherapy in based on one-to-one contact; besides, if practiced in a group format, not only is interaction with the facilitator exploited but group interactions are used as well.

Thus, in this article, bibliotherapy is understood as an intervention that uses literary texts and guided group discussion to promote self-understanding, cognitive, emotional, behavioral and spiritual 
change in patients. Instead of highly denotative texts appealing to consciousness, rationality and apprehension, it builds upon artistic, connotative texts that have an effect also on the unconscious, on the emotional and on the spiritual, and bring about changes resulting from recognition and understanding.

Building upon the multiple possibilities of meaning conveyed in symbolic or metaphoric poetic expression, group interactions may free the imagination and creativity-two invaluable skills in finding new meaning and rebuilding purpose in life. In line with Viktor E. Frankl's approach of logotherapy, the meaning of life may be found through experience and creation, which in the case of bibliotherapeutic intervention comes into being first and foremost by experiencing and secondly by creating literary works of art. This form of expression in itself may suggest order and reliability, which is reassuring in the disorderliness of the illness experience. Narrative forms commend causality and presume a reader who can fabricate a meaningful story out of the narrative bits and pieces of postmodern fiction. These works have to be open works in the Umberto Ecoian sense; that is, by leaving space for the reader to complete the work, they insist upon their response, and thus effectuate an interactive process where the reader is not only a passive recipient but an active shaper of the unfolding story.

These works of literature may perform well in bibliotherapeutic group intervention because they refocus the attention of patients, thus expanding their shrinking world. In the distress caused by cancer diagnosis and grueling treatment, self-protecting mechanisms may weaken, and literary works offer a mild, agreeable, nonviolent means of confrontation. Patients draw parallels with their lives and experiences, judge characters and their motivations, evaluate life philosophies, and may or may not open up, thus expressing their ideas and feelings in the group. Literary works serve as a surface of projection of inner thoughts, feeling, anxieties and concerns. It is the responsibility of the bibliotherapist to encourage and safely channel manifestations to achieve the desired outcomes.

Bibliotherapy has been applied with various therapeutic or developmental goals for over a century according to the target audience: children, youth, and adults or the elderly of different racial, gender, and socio-cultural backgrounds or health statuses. It may be an enjoyable and easy-to-acquire means of self-understanding, personality development, mental health promotion, or complementary therapy to support one's healing, improving or maintaining one's health status (Béres 2017). It has been found beneficial in addressing mental health problems such as stress, depression, anxiety, and psychological disorders (Gots 2016).

A recent systematic analysis of published literature evaluates the efficacy of bibliotherapy in alleviating the psychosocial health problems of cancer patients. Patient-reported outcomes associated with bibliotherapy included improved coping skills, reduced levels of anxiety and depression, increased self-esteem, social function, quality of life, better interpersonal, family, school, and global QoL, self-efficacy, perception of helpfulness and perception of support. All nine studies included in the analysis concluded that bibliotherapy was beneficial for patients with cancer; however, the small sample sizes and various measures for specific outcomes limit the generalizability of the findings. Thus, the authors agreed that the strength of the association between bibliotherapy and therapeutic benefits needs standardized measurement and further comparison (Malibiran et al. 2018).

The replication of the beneficial effects of the bibliotherapeutic intervention should be possible through all the elements that form the frame of the intervention (its length, number and type of patients, design and frequency of sessions, namely warming or structured exercises, text reading, opening questions, facilitated discussion, closing part). The critical component of the replication of outcomes is the facilitator; that is, his or her skills in choosing the appropriate texts and his or her group-leading experience. Certain texts may have a reputation concerning their usability in bibliotherapeutic interventions (Berthoud and Elderkin 2013). However, their linguistically and culturally determined value does not subsist for long due to the constant change of literary styles, modes of expression, culture and society. In spite of this, the practically inexhaustible well of artistic human self-expression within and across each language and culture represent a huge possibility for tailoring the bibliotherapeutic intervention as needed; that is, texts will remain the ever-changing constituent of the bibliotherapeutic intervention, and bibliotherapists have to adjust them to the 
appropriate profiles of patients. Thus, it is an unrealistic expectation to select a set of texts that will produce the same group dynamics and insights across different cultural and socioeconomic contexts.

\subsection{Initial Considerations and Recruitment}

Initial considerations for establishing groups included theoretical as well as practical issues, as summarized in Table 1.

Table 1. Initial considerations for group formation.

\begin{tabular}{ccccccc}
\hline $\begin{array}{c}\text { Number of } \\
\text { Participants }\end{array}$ & $\begin{array}{c}\text { Time and } \\
\text { Duration of } \\
\text { Sessions }\end{array}$ & Venue & Openness & Recruitment & Assessment & $\begin{array}{c}\text { Duration of } \\
\text { Group } \\
\text { Therapy }\end{array}$ \\
\hline 5-12 & $\begin{array}{c}\text { late morning } \\
2 \text { h-long }\end{array}$ & $\begin{array}{c}\text { Group therapy } \\
\text { room at the } \\
\text { Oncology Clinic }\end{array}$ & $\begin{array}{c}\text { Group closes } \\
\text { from third } \\
\text { session }\end{array}$ & $\begin{array}{c}\text { Through medical and } \\
\text { onco-psychological } \\
\text { staff, posters, leaflets, } \\
\text { Facebook posts }\end{array}$ & $\begin{array}{c}\text { Evaluation } \\
\text { interview by } \\
\text { the clinical } \\
\text { psychologist }\end{array}$ & $\begin{array}{c}\text { Ten weekly } \\
\text { sessions }\end{array}$ \\
\hline
\end{tabular}

The number of participants was planned according to a small group format (5-12 persons) in order to achieve optimal interactivity. Although the group was planned to be led in co-therapy, which would have allowed for a larger group, it was considered beneficial to stick to the small group format in order to minimize any temporary anxiety caused by the group setting, challenges of new acquaintances, and the higher demand for attention. Thus, the first group included six persons, and the second and third groups included nine persons. Accordingly, the relatively small number of participants and homogeneity in terms of sex and cancer type resulted in a warm and highly supportive first group. The second and third groups were more heterogeneous in sex and cancer type, which effectuated the apparition of subgroups and resulted in a more powerful group dynamic.

Late morning hours (10-12 a.m.) were suitable for most outpatients. Unfortunately, patients who had just resumed work could not attend these sessions. The time was set mainly to support those in treatment or rehabilitation in the first place. The venue was a dedicated space for group therapy within the Oncology Clinic. Thus, temporarily hospitalized patients could easily attend sessions, as took place once in the first group. The duration of $2 \mathrm{~h}$ was set to fit the energy level of patients commonly challenged by fatigue. The time frame was strictly respected throughout all sessions and groups.

The first two sessions were open for would-be attendants. From the third session on, the group was closed, and a commitment was expected to remain within the group throughout the whole process of upcoming sessions. However, in a few instances, medical appointments hindered attendance, and this was regarded as justified absence.

Recruitment periods consisted of 2 months preceding the first sessions. Means of recruitment included A3 posters in the waiting halls of the Oncology Clinic at first, which was then expanded to two other clinics (Urology and Dermatology), leaflets at the patient information desk, mailing list notification through a cancer support association, and Facebook posts by the bibliotherapist. Personal recommendations of members of the onco-psychological team proved to be more effective; however, all other channels attracted members also. As a consequence of the recruitment method, only three participants were not included in either individual therapy or group therapy before or during bibliotherapy.

A formal assessment interview was held by the clinical psychologist only if the patient had not been in touch with the onco-psychological team. Otherwise, their recommendations were accepted.

The institutional background is an essential part of the therapeutic framework in a group setting. The duration of therapy had to be adapted to other group interventions of the clinic. According to previous experience related to the length that patients can stay in therapy and the duration of Simonton trainings based on imaginative techniques, a 10 week-long period was assigned to the bibliotherapeutic group intervention. The length of intervention will be evaluated later in Section 3. 


\subsection{Selection of Patients}

The selection of participants followed the principles summarized in Table 2.

Table 2. Selection criteria.

\begin{tabular}{ccc}
\hline Inclusion Criteria & Exclusion Criteria & Not Required \\
\hline $\begin{array}{c}\text { Motivation to join the group voluntarily and not } \\
\text { due to compliance with caregivers }\end{array}$ & $\begin{array}{c}\text { Cancer quickly progressing to a } \\
\text { life-threatening phase }\end{array}$ & A habit or passion for reading \\
\hline $\begin{array}{c}\text { Determination to engage in his/her own healing } \\
\text { through change and exercise of control }\end{array}$ & $\begin{array}{c}\text { Types of cancers that affect the inclusion } \\
\text { criteria (e.g., certain brain tumors) }\end{array}$ & $\begin{array}{c}\text { Prior knowledge of literature } \\
\text { or any erudition }\end{array}$ \\
\hline $\begin{array}{c}\text { Suitability for the therapeutic method: good } \\
\text { verbal skills (no sensorial aphasia), good hearing, } \\
\text { ability to relate and interact with others }\end{array}$ & $\begin{array}{c}\text { Treatments endangering other patients } \\
\text { (radioactivity) }\end{array}$ & Literary skills \\
\hline $\begin{array}{c}\text { General physical status (able to sit comfortably } \\
\text { during meetings) }\end{array}$ & $\begin{array}{c}\text { Personality or mental disorders that affect } \\
\text { mental and cognitive functions (e.g., } \\
\text { previously diagnosed and treated } \\
\text { schizophrenia) }\end{array}$ & \\
\hline $\begin{array}{c}\text { Adequacy of personality traits: open, ready to } \\
\text { put into words his/her own experiences, } \\
\text { interested in others' communication }\end{array}$ & $\begin{array}{c}\text { Other generally accepted criteria of } \\
\text { exclusion in group therapy (addicted, } \\
\text { institutionalized, instable, etc.) }\end{array}$ \\
\hline
\end{tabular}

The exclusion criteria had to contain certain types of fulminant cancers as they can obstruct patients from completing therapy. Since the group was intended for nonterminal patients (with lower grades than 4), a potential loss of attendees would have implied a stress factor, risking the overall well-being of attendees and the success of intervention.

\subsection{Participant Data}

In total, 12 persons obtained inclusion in the first group, nine attended the first two sessions, and six committed to the whole course of therapy. No drop-outs were seen in the second and third groups. Contrary to the first two groups, four persons joined the third group from the previous two groups at their own request, which is indicated by their participant code in Table 3 summarizing all patient data.

Table 3. Summary of participant data for all groups.

\begin{tabular}{|c|c|c|c|c|c|c|c|}
\hline $\begin{array}{l}\text { Participant } \\
\text { Code }\end{array}$ & $\begin{array}{c}\text { Age } \\
\text { (years) }\end{array}$ & $\begin{array}{l}\text { Which } \\
\text { Group? }\end{array}$ & $\begin{array}{l}\text { Cancer } \\
\text { Type }\end{array}$ & Grade & $\begin{array}{c}\text { Previous Group } \\
\text { Intervention (Simonton)? }\end{array}$ & $\begin{array}{l}\text { Individual } \\
\text { Therapy? }\end{array}$ & $\begin{array}{l}\text { Individual Support } \\
\text { by Psychiatrist? }\end{array}$ \\
\hline A & 56 & 1 & Breast & 2 & yes & yes & yes \\
\hline $\mathrm{B}$ & 55 & 1 & Breast & 2 & no & no & no \\
\hline $\mathrm{C}$ & 43 & 1 & Breast & 2 & yes & no & yes \\
\hline $\mathrm{D}$ & 51 & 1 & Breast & 3 & yes & yes & no \\
\hline$E^{*}$ & 40 & 1 & Colon & 3 & no & no & yes \\
\hline $\mathrm{F}$ & 66 & 1 & Breast & 1 & yes & yes & yes \\
\hline G & 62 & 2 & Brain & 3 & no & no & yes \\
\hline $\mathrm{H}^{*}$ & 33 & 2 & Melanoma & 3 & no & yes & no \\
\hline I & 50 & 2 & Breast & 2 & yes & yes & yes \\
\hline $\mathrm{J}$ & 64 & 2 & Lung & 2 & yes & no & no \\
\hline $\mathrm{K}$ & 63 & 2 & Breast & 3 & yes & yes & no \\
\hline $\mathrm{L}$ & 69 & 2 & Breast & 1 & no & yes & yes ** \\
\hline M & 58 & 2 & Breast & 1 & yes & yes & yes \\
\hline $\mathrm{N}$ & 46 & 2 & Breast & 3 & yes & yes & no \\
\hline $\mathrm{O}$ & 62 & 2 & Colon & 2 & no & no & no \\
\hline A & 58 & 3 & Breast & 2 & yes & yes & yes \\
\hline $\mathrm{P}$ & 58 & 3 & Breast & 1 & no & yes & no \\
\hline $\mathrm{R}$ & 28 & 3 & Testicular & 3 & yes & yes & no \\
\hline$S$ & 34 & 3 & Breast & 3 & yes & yes ** & no \\
\hline M & 59 & 3 & Breast & 1 & yes & yes & yes \\
\hline $\mathrm{T}$ & 40 & 3 & Melanoma & 2 & no & yes & no \\
\hline $\mathrm{U}$ & 56 & 3 & $\begin{array}{c}\text { Breast, } \\
\text { melanoma }\end{array}$ & 3 & yes & yes & no \\
\hline $\mathrm{O}$ & 63 & 3 & Colon & 2 & no & no & no \\
\hline $\mathrm{F}$ & 68 & 3 & Breast & 1 & yes & yes & yes \\
\hline
\end{tabular}

${ }^{*}$ Deceased after 14 and 12 months following the end of group intervention. ${ }^{* *}$ Outside the care of the Oncology Clinic. 
In total, $60 \%$ of patients had breast cancer, $10 \%$ had colon cancer, $15 \%$ had melanoma, $5 \%$ had brain cancer, $5 \%$ had testicular cancer, and $5 \%$ had lung cancer. Women made up $95 \%$ of patients. On the group level, the diversification of patients was only achieved gradually as recruitment could be extended to further clinics treating different cancers (e.g., urologic, dermatologic).

\subsection{Group Design, Use of Literary Texts}

A typical session was made up of the following: a warm-up task introduced the session (approximately 20-25 $\mathrm{min}$ ), and the reading of the fictional text followed (maximum $20 \mathrm{~min}$ ); then, a detailed discussion was facilitated, and a closing circle ended the session. Occasionally assignments for optional individual homework (e.g., poem writing, ending stories, transcribing patterns, etc.) were also offered.

The text was usually read by the bibliotherapist with only one exception in each group. After the introductory sessions, we always started our series of texts with a folk tale, because their inherent symbolism and universal relevance equip patients for the bibliotherapeutic way of reading. These tales were not read but always told by heart as the traditional storyteller style requires. In the choice of texts, we sought texts which were unknown for patients, sometimes removing authors' names to provide a primary experience without cultural or intellectual preconceptions or learned information that could distort the common experience or could allow participants to resist through intellectualization. Sometimes, reading was suspended at points of interest of the unfolding narrative to explore patients' imagination regarding the evolution of events or characters.

The first sessions provided the foundation for upcoming group work by negotiating the rules. Open communication was encouraged; nevertheless, attendees were asked to guard the extent and depth of their disclosure to the limits of their feeling safe. Confidence rules applied to everything shared to achieve complete trust and a sense of safety throughout the process of group sessions. The group nurtured a culture of equality of persons, contributions and issues, and aimed to provide an equal opportunity for profiting from sessions. The group adhered to value neutrality; i.e., it accepted different worldviews and values as equal and valid. Absences had to be indicated and accounted for in anticipation.

Texts were carefully chosen to address issues of interest for patients and to support group dynamics. Last but not least, texts were meant to give an aesthetic experience and emotional satisfaction as well. They had to enlarge the horizons of readers to make them conscious of the infinite width of their life and meaning-making possibilities. We found that issues of interest covered general topics such as gender roles, family and marital relationships, vocation and self-fulfillment, freedom and subordination, taking difficult decisions, finding meaning in everyday life and illness experience, expression of feelings and wishes, resilience and communication, etc. All these may have appeared as the main theme of a piece of literature or be hidden as a detail. It was always the responsibility of the bibliotherapist to decide how much emphasis to give to a lingering topic through text choice; e.g., the topic of death was the main focus of a Hungarian short story that was read in a session: an old man with an excellent sense of humor plays a joke on his nephew and only heir by faking a death agony and thus tricking him out of some money in the presence of the large audience of the village. Another short story included a love relationship: as a premonition of the inevitable split of the lovers, the dog of the hero dies. In this instance, this was only a minor detail that alluded to death as a possible topic for discussion. In our experience, pieces of contemporary (culturally close; that is, mainly Hungarian) literature suit our bibliotherapeutic aims the best because the cultural and linguistic synchronicity makes understanding and identification instantaneous; at the same time, women's issues are highly represented by present-day women writers.

We are aware that texts should be culturally relevant, easy to understand, and appropriate to the socioeconomic status of patients. Nevertheless, even highly qualified patients may express their dislike regarding certain genres or particular texts. One of the patients in the first group expressed her disappointment when we turned to reading a poem after a series of narrative texts. Although we often 
felt that facilitating discussion around a poem is more difficult as exchange is repeatedly interrupted by silent periods, feedbacks have shown that the emotional experience and insights of these sessions outweighed those for narrative texts.

The theme of death is expected to arise in each group, since one of the causes of distress in patients is death anxiety. When we assessed signs of death anxiety in this working phase, we chose to bring the theme in through the text with the dying dog already mentioned. The excerpt was about the wondrous love relationship of a youngster with a beautiful double-natured creature (a migratory bird and a young woman). Her dilemma of whether to stay in the relationship and decline in vigor or to part and live on touched participants as it alluded to living with unsolved challenges. One participant shared her strong feelings of anxiety regarding a world that is not a safe place for her children any longer, because if she might die, then her husband might die as well. The group reacted supportively to her disclosure, and instead of turning away or tabooing death, opened up for the difficult question of imminent death. The secret of the fictional character's hidden nature gradually poisoned the initial trust and confidence in the story. Another patient took the courage to open up regarding the last days of her mother, and with this contribution, she connected both the secrecy motif of the text and the sharing of the former patient. The following feedback from the closing form of one participant referred especially to this session: "a positive effect, not only on myself, but on the life and way of thinking of my husband as well. I understood that we may be able to come to terms even with bad things if we speak up. This is not what I have been brought up in; I have just come to realize how important this is, and I would like to teach this to my children as well. My husband also profited from our discussions after sessions, because he could also express his own thoughts and feelings".

Group dynamics were always taken into account in the choice of texts. One participant shortly alluded to her mixed feelings towards her husband; the group did not react with empathy, and we therefore decided to focus on relationships in the next session. We chose a text written as a mother's letter for her son about the truth regarding her marriage to the child's father. More participants shared their true version of their marital (or extramarital) relationships, and as a consequence, we could facilitate a re-enactment and a correction of the former rejection.

The various patterns of relationships of patients influenced the choice of a poem that enumerated powerful images and metaphors regarding the various ways people can love. Some images implied harmonious connections, while others presented bizarre relationships, even evoking wartime. Many participants felt portrayed themselves and came to important insights.

Group dynamics are considered as important as texts. In the first phase of the group process, the foundation of the group, the establishment and solidification of rules, and arousal of interest are the main focus. It is a major concern to build trust as the exchange begins. These aims can be best achieved through texts that assist introductions (mainly poems) and by offering short written exercises such as paraphrasing/customizing texts, filling in and sharing bulleted poems, etc. for the affirmation of self-identity. Structured group exercises may prevent the outpouring of personal disease histories that may be intimidating for some of the members. As everybody is well aware that fellow cancer patients are included in the group, it is unnecessary to disclose diagnoses and treatments in much detail in the beginning.

Once reaching a working phase (at the fourth or fifth session), longer texts with more complex issues may be addressed. It is in this phase that the assessment and addressing of major issues take place. In our experience, more homogenous groups develop a more supportive attitude, while more heterogeneous groups work better on confronting members and debating views, which proved to be efficient in attitudinal or behavioral change.

The third phase involves the termination of group processes and enables patients to move on. However, as anticipated, the number of sessions proved to be less than enough to address all concerns and needs of patients. Thus, after the evaluation of participation and outcomes, some of the members continued with individual or different oncoming group therapies. 
Texts and dynamics—-both ingredients of the bibliotherapeutic intervention-are subordinated to participants' interactions and mutual sharing, since self-understanding and growth can be achieved through these.

\section{Results and Discussion}

We present our results from an analysis of our minutes and written feedback of patients using the spiritual assessment tool of SAIL (Spiritual Attitude and Involvement List), which defines spirituality as "one's striving for and experience of connection with the essence of life" (de Jager Meezenbroek et al. 2012b). This connection may be manifested in three relations: one's connectedness with oneself, one's connectedness with others and nature, and one's connectedness with the transcendent. We embrace the definition of spirituality by de Jager Meezenbroek et al. as suitable for encompassing theistic and nontheistic spirituality simultaneously without trying to delimit the ever-changing religiosity and religion from spirituality. Analyzing the thematic affluence of the sessions, we marked all main topics shared as either belonging to connectedness with oneself (I), with others or nature (II), or with the transcendent (III). Whenever we have found that the personal narrative may be classified into more than one relationship, we opted to create separate entries. In some cases, the second or third kinds of connectedness were felt as a latent need, since they were not explicitly expressed. Our results are summarized in Table 4.

Table 4. Summary of spiritual needs and topics.

\begin{tabular}{|c|c|c|c|c|c|}
\hline I & II & III & I-II & II-III & I-II-III \\
\hline Authenticity & $\begin{array}{l}\text { Family as } \\
\text { resource }\end{array}$ & $\begin{array}{c}\text { Faith in God } \\
\text { and/or afterlife }\end{array}$ & Fear of death & $\begin{array}{l}\text { Wish for } \\
\text { holidays }\end{array}$ & Inertness \\
\hline Deficiencies & Loneliness & $\begin{array}{l}\text { God, faith in } \\
\text { God }\end{array}$ & Loss of family & Chance & Remorse \\
\hline Duality, inner conflict & & Prayer & Loss of work & Sacred symbols & Righteousness \\
\hline Fear of future (relapse) & & $\begin{array}{l}\text { Transcend } \\
\text { reality }\end{array}$ & $\begin{array}{l}\text { Need for } \\
\text { recognition }\end{array}$ & & Self-accusation \\
\hline Freedom of choice & & & Origins, legacy & & $\begin{array}{c}\text { Transgenerational } \\
\text { trauma }\end{array}$ \\
\hline Freedom & & & Right to life & & Euthanasia \\
\hline Indetermination & & & Role conflicts & & \\
\hline Life vocation & & & $\begin{array}{c}\text { Speaking about } \\
\text { death with a child }\end{array}$ & & \\
\hline Loss of body integrity & & & $\begin{array}{l}\text { Stuck in the sick } \\
\text { role behavior }\end{array}$ & & \\
\hline \multicolumn{6}{|l|}{ Recognition of life } \\
\hline \multicolumn{6}{|l|}{ Unfulfilled vocation } \\
\hline \multicolumn{6}{|l|}{ Uniqueness } \\
\hline \multicolumn{6}{|l|}{ Wish for control } \\
\hline Wish for secrecy & & & & & \\
\hline
\end{tabular}

In order to present the reasons for the successful use of bibliotherapy both in revealing and addressing spiritual needs, we include some replies from our feedback form that were completed after the closure of interventions. The open questions of the form looked for the most impressive and profitable texts, themes discussed, and facilitated a self-evaluation of the intensity of the participant's inner work in the group, etc. Most importantly, the form included the following: "What effect did the group have on your life and everyday welfare?" (Bálint 2018). Whenever we quote from the feedback form, this is indicated.

Among all concerns and worries discussed, the ones revealing personal quests, inner conflicts, issues of connectedness to the self were the most numerous. One may discover recurrent themes of cancer patients such as loss of body integrity, deficiencies, indetermination, fear of relapse, or fear of not being able to achieve one's life mission or vocation, while others include general human concerns 
of freedom, authenticity, uniqueness, freedom of choice, recognition of life, a weighing of achievements and a well-lived life. We have found that cancer as an illness affected the mental health of our patients not only by causing distress and a great number of bodily symptoms but by reviving buried psychosocial or spiritual problems, such as inner conflict. One of the approaches towards fighting cancer was through solving major life problems for our patients. Some of the disclosures had to be considered as indirect communication; i.e., the patients disclosing them might not yet be aware of their actual needs. One of the patients displayed an extreme wish for secrecy, in that she was unwilling to share the facts of her disease and treatments outside her closest family. We could identify this as an underlying need for self-authority and restoring control over her life. Accordingly, as she progressed in maintaining control over her state, her secretive attitude changed. A healthy connectedness to the self was displayed when one patient evoked a childhood memory of witnessing a car accident involving some close relatives. The supportive experience and satisfaction of being able to help as a child in an extreme situation equipped her with a strong belief and self-confidence of being able to cope with her own extreme life-threatening condition. One piece of feedback from the first group states, "I could feel through these pieces of literature that I came closer to myself-it was here that I was able to fully experience and show my feelings - thus, my anxiety subsided, and I found new opportunities and solutions for my life".

The need for connectedness to others or nature in its pure form occurred in narratives about family relations and loneliness. The very existence of the group addressed this. Meeting or keeping in touch outside the group was regarded as optional and not discouraged in the least. Support available in self-help groups is important and promoted by many activities organized by the oncology clinic and a local association; e.g., healthy cooking, remedial gymnastics, yoga practice, etc. A sense of belonging could also be experienced in different groups in outdoor activities. Many of the patients developed habits and hobbies connecting them to nature, such as walking and running or Nordic walking, sometimes accompanied by an interest and attachment to pets.

One of the meaning-making hobbies connecting participants sprang from a structured group exercise based on short advertisements in the first group. Participants were asked to choose two different advertisement texts: one that benefitted themselves, and another one that might benefit somebody else in the group. Thus, one participant offered a dancing class. At the beginning of the next session, she acknowledged having actually contacted a ballet teacher, and kept going to ballet classes once a week since then. This outcome was significant since she had a submissive personality and was prone to depression. Another structured group exercise for introductions used at the beginning of the third group asked the participants to form a brief, true statement consisting exclusively of one's name and a matching predicate. The statements were so appropriately formulated that participants kept alluding to them throughout the intervention. "Fiona feeds" conveyed the participant's longing for and constant enjoyment of all kinds of connections which she obtained and maintained through extensive cooking habits. Indeed, the author of this short introductory sentence fulfilled her self-determination by inviting the group for dinner after the last session.

We experienced another way of connecting to one another in the group: sympathies and connections evolved according to a complementing pattern. Participants sympathized with other participants if they realized that the others complemented their weaknesses. For instance, a patient with an unsatisfying marriage sympathized with another one who referred to her husband as her main support and resource. Other pairs were formed in line with their contrasting attitudes towards money or religious festivals. They seemed to represent a source of interpersonal learning for one another. Lastly, we quote from the feedback form: "[the group] gave me a feeling of belonging, which I usually miss so much. It is important that we formed a fellowship of true fellows, since we can discuss all the things others do not want to hear. I felt calmness in the group, which even followed me throughout the day. My main experience: how important it is to pay attention to one another". We can conclude that connections are an important source of strength and vigor-truly, the essence of life. 
The topics and needs enumerated under categories I-II belong both to connectedness to the self and to others. This list includes topics of fear of death, loss of family, loss of work, need for recognition, one's origins and legacy, right to life, role conflicts, speaking about death with one's child, and being stuck in the sick role behavior. Loss of work was raised in all three groups and kept recurring in many instances. For a young teacher, this meant not only utmost meaningfulness but connectedness to others, to the world and to life in general. For another patient, it served as a compensation for childhood neglect through the appreciative attention captured through work. Fulfillment in work represents social utility-a sense of being of service to fellow humans, whose recognition attests one's authenticity, which presumes meaningful connections. Questions of origin and legacy occurred as needs but also as powerful resources. A right to life is not enough to be set as a demand-it must also be acknowledged and nurtured by others. Trapped between ageing parents needing support and a seriously ill son in need of permanent supervision, one of our patients was denied the right to live a life of her own. Family narratives about challenges and coping with former generations served as a model and resource for coping. Being stuck in the sick role behavior is a deficit in authenticity, but in this particular case, it revealed a strong need for and a fulfillment of connections and intimacy. We classified an ardent talk about how and when to talk about death with a child as pertaining to this category because the need provoking the discussion turned out to be a need for close relations who could take care of the patient's supposed orphans in case of their passing away. The patient's anxiety about the future and the possible inability to raise her children was successfully addressed during sessions through the understanding and emotional support of the group. Role conflicts also pertained to this group because they hindered harmonious connections with the self and others. A young woman had already struggled with the conflict of being a mother, a student, and a wife-being a cancer patient only added to the confusion.

Connectedness to the transcendent occurred in two groups in different contexts. Once, it was brought into focus by evoking demanding periods of history-the survival of ancestors served as a resource for the spiritual need that had just surfaced. One patient directly expressed a wish to exploit childhood memories of attending church, of sitting and being immersed in silence as a spiritual exercise rather than a religious practice. In another instance, it appeared as a resource originating in the patient's earlier experiences of extreme life risk and need for providence. Having displayed great confidence and calmness as a result of the "always close means" of prayer, she induced interest in a fellow group member. However, the latter translated her spiritual stance into a means of outward religious practice, and eventually ended up frustrated by visiting church with her unwilling family. We share this case to show that although spiritual needs and coping mechanisms may be brought into light, addressing them is not always successful for a number of reasons. In this particular instance, we explain this failure by the marital conflict that overtook church visits and diverted the patient from her original intention. The means were turned into an aim instead of the means serving as a form of help to achieve an aim.

A few items could be classified under categories II-III as well, such as the wish for holidays, chance, and sacred symbols. The explicit wish for holidays suggests a need for connections and joy, which are realized in the habitual meeting of family members and friends during holidays, but may suggest a latent need for transcendence as well, as the traditional differentiation of working days and holidays is based on a sacred understanding of time. As the origin of the word ("holy day") still suggests, holidays imply a time set apart for the veneration of the divine, which is often performed in a community. One has to experience the feelings of belonging, of being accepted and loved first in human relationships, and one can transform and project this experience onto the divine in order to establish a relationship with it. Patients may seek transcendent guidance whenever they attribute meaning to minor events of everyday life. One narrative exemplifying this described meeting a woman in a lovely red coat sitting on a bench in a public playground and eating calmly in heavy rain. The unexpected sight became a symbol of tranquility and joie de vivre in the midst of challenging circumstances, and thus became a visionary revelation transcending the sphere of the logical and ordinary. Another 
narrative encoded the close flight of crows as a symbolic expression of being invisible or unsafe, which could be confirmed by the family events and relationships of the patient. Sacred symbols appeared on the enamel pendants of one patient who crafted, for instance, the individual angel silhouettes of all group members at the end of the sessions.

Spiritual needs pertaining to all three categories proved to be the most complex issues of sessions. Remorse, self-accusation and need for righteousness, although originating in different narratives of different patients, are close to one another. They call for relief, forgiveness, and self-acceptance. Some patients may have been of the view that serious illness is caused by a committed mistake, fault or even sin according to the religious overtone attached; thus, guiltless connectedness to the self was no longer possible. Moreover, parents with underage children often feel remorse for not being able to raise their children or for letting them be raised by step parents. We encountered remorse regarding survival in one of our patients who prepared and attended the funeral of a cancerous relative. However, longstanding self-accusations also came into light; for example, regarding not performing as expected for a parent with dementia, or accidentally missing the death of a beloved parent. As for why questions concerning the origin of an illness lead to the limitation of human existence, as a recourse to transcendental meaning-making, one patient offered the following quotation from the Bible: "all things work together for good to them that love God". Handing over control to medical staff was complemented with a wish to hand over control to an all-knowing, powerful being, who would and could care for all things outside the patient's reach. Sometimes, it takes time to discern a need for transcendence from psychological regression due to the vulnerability of being ill. Our therapeutic aim was to encourage patients to find the balance of an enabling faith which went hand-in-hand with taking control of all things within their reach and a confiding faith in things outside human reach.

Transgenerational traumas could be assessed in two groups. Two cases were related to sexual misconduct and affected the way patients thought about the origin and justification of their existence. The text that evoked one of the cases consisted of the inner narration of an old woman preparing for death, who was tempted in her youth to accept the admiration and love of a medical doctor at the bedside of her sick child while her husband was fighting in the war. She remained faithful, but she considered herself to have failed in spirit and experienced remorse for a long time. Participants could identify with this groundless shame shared by victims of violence or dominance. In one case, we could discern the pattern of life of a former generation present in the decisions and lifestyle of a participant. Her aunt lived in a family with a burdensome number of children and decided to become a nun at an early age on the practical grounds of doing a favor to her parents by becoming self-sustaining. The niece followed this self-sacrificing lifestyle (refusing to marry her love, giving up her original profession, serving the wellbeing of her mother until death, etc.). The group challenged her submissive behavior and denied her approval, however noble or elevated her arguments sounded. The acceptance of the fact that events and former generations highly affect one's life itself requires spiritual maturity. The arising of questions concerning euthanasia also revealed multiple needs for self-determination, safety, reliance on trustful relationships, and above all, the complex interconnectedness of all spiritual needs.

\section{Conclusions}

We have analyzed the minutes and written feedback of our bibliotherapeutic group interventions in the search for the spiritual needs directly and indirectly expressed by nonterminal cancer patients during sessions. The various and multiple needs identified and classified as spiritual indicate that bibliotherapy as an intervention technique is capable of bringing into light the spiritual needs of patients. During interactions facilitated by reading and discussing works of literature, patients express their needs in the form of direct and indirect communication. The intervention is able to help them recognize and verbalize their needs without orientating their thoughts or suggesting ideas. If participants are already aware of needs, group interventions are beneficial in voicing them and in instantly allowing participants to experience their justifiability in the group interaction. Group bibliotherapy is also successful in inciting patients to look for ways of meeting and addressing these needs assertively. As we have 
shown, some of these needs-such as connectedness to others within the group, or connectedness to the self by restoring control, alleviating death anxiety, diminishing stress caused by role conflicts, setting goals and priorities, or connectedness to the transcendent through exercising understanding and using symbolic language-were addressed during sessions. Consuming and creating art, which is a symbolic expression in itself, is a universal way of experiencing transcendence. Creating and consolidating a reflective reading habit is beneficial outside the therapeutic setting as well. Bibliotherapy equips patients with a skill to be taken away and be used continuously.

The strongest benefit of bibliotherapy in terms of spiritual needs is that it can reveal undetected needs as soon as patients have an insight of or become conscious of them. Contrary to the well-designed assessment tools which ascertain the known needs of a fixed moment over the long-lasting time interval of treatment, the bibliotherapeutic intervention explores already known and still unknown needs as they change; i.e., as they appear, are attended to, change or subsist. Moreover, a part of these needs can be addressed as soon as they arise through support and feedback from group members, through the information shared, social skills learned, and the imitation of the thinking and behavior of fellow members. As we have noted in the Introduction, the influence of spirituality and religion is not always beneficial. During the process of a bibliotherapeutic intervention, one may also ascertain whether the influence of spirituality and religion is beneficial or harmful.

Having listed some of the benefits of the bibliotherapeutic intervention, we must consider the risks as well. We have presented it as an advantage that texts serve as a projection surface and patients may choose how much they reveal of what has touched them; we have to mention the same as a risk as well. Texts may provide a shield behind which patients may hide if they decide not to reveal their involvement. Professional reflections of criticism may add to rationalization and intellectualization as defense mechanisms (to minimize this, we usually removed the authors or titles of texts that could have induced a purely intellectual approach). However, one may remain in a voyeuristic position and profit in only a very limited way from attendance.

We consider the required limitation of the length of the group process to 10 weeks as a risk. The number of sessions proved to be less than optimal for achieving change in all detected areas. For this reason, we encouraged patients to continue psycho-spiritual therapy where and however possible. Nevertheless, we consider it a success of the bibliotherapeutic intervention that, after experiencing the benefits of therapy, some patients committed to seeking further individual therapy.

The major limitation of published studies of bibliotherapeutic interventions is the relatively small sample sizes (Malibiran et al. 2018). Our findings share the same limitation, as the total number of our attendees in the three groups was 24 . The bibliotherapeutic intervention in usually delivered in a small-group setting, which conveys this limitation in itself.

Further research is required to measure the efficacy of the bibliotherapeutic intervention in the assessment of spiritual needs of cancer patients. Comparisons with already available assessment tools could provide further insights into this question. In our next study, we intend to collect data before the bibliotherapeutic intervention in order to compare these with the needs verbalized during sessions and/or identified through the bibliotherapeutic group intervention. For this purpose, we plan to produce and use the Hungarian version of the SAIL assessment tool. Similarly, further research could deepen our understanding of the extent to which the bibliotherapeutic intervention can address spiritual needs. We plan to use interviews following the closure of the intervention to determine the efficacy of the intervention. Moreover, once the Hungarian version of the SAIL assessment tool is made available for clinical use, a more comprehensive assessment of spiritual needs may be expected. Thus, further bibliotherapeutic interventions could be designed to address the spiritual needs of patients more specifically.

One patient's feedback stated that, through bibliotherapy, she attained a clearer sight of her past and a more livable present. It was our privilege to admire the strengthening, the multiplication and the personalization of patients' expectations and plans for the future as they truly turned from passive recipients into the increasingly active shapers of their unfolding life story. 
Author Contributions: Conceptualization, Á.B.; data curation, Á.B., J.M.; writing—original draft preparation, Á.B.; writing-review and editing, Á.B. All authors have read and agreed to the published version of the manuscript.

Funding: This research received no external funding.

Acknowledgments: The authors would like to thank Mónika Mailáth her collegial support, and the administrative and psycho-oncologic team of the Oncology Clinic, Faculty of Medicine, University of Debrecen. We would like to thank Balázs Venkovits (Institute of English and American Studies, University of Debrecen, Hungary) for proofreading the manuscript prior to submission.

Conflicts of Interest: The authors declare no conflict of interest.

\section{References}

Bálint, Ágnes. 2018. Kalapba zárt lányok: Biblioterápia az onkológiai betegek támogatásában. Embertárs: Ökumenikus lelkigondozói és mentálhigiénés folyóirat 16: 330-52.

Béres, Judit. 2017. “ . . a azért olvasok, hogy éljek” Az olvasásnépszerüsítéstől az irodalomterápiáig. Pécs: Kronosz.

Berthoud, Ella, and Susan Elderkin. 2013. The Novel Cure: An A to Z of Literary Remedies. Edinburgh: Canongate.

Best, Megan, Carlo Leget, Andrew Goodhead, and Piret Paal. 2020. An EAPC white paperon multi-disciplinary education for spiritual care in palliative care. BMC Palliative Care 19: 9. [CrossRef] [PubMed]

Bibliotherapy. 2016. Available online: https://www.goodtherapy.org/learn-about-therapy/types/bibliotherapy (accessed on 20 January 2020).

Büssing, Arndt, and Harold G. Koenig. 2010. Spiritual needs of patients with chronic diseases. Religions 1: 18-27. [CrossRef]

de Jager Meezenbroek, Eltica, Bert Garssen, Machteld van den Berg, Dirk van Dierendonck, Adriaan Visser, and Wilmar B. Schaufeli. 2012a. Measuring spirituality as a universal human experience: A review of spirituality questionnaires. Journal of Religion and Health 51: 336-54. [CrossRef]

de Jager Meezenbroek, Eltica, Bert Garssen, Machteld van den Berg, Dirk van Dierendonck, Adriaan Visser, and Wilmar B. Schaufeli. 2012b. Measuring spirituality as a universal human experience: Development of the Spiritual Attitude and Involvement List (SAIL). Journal of Psychosocial Oncology 30: 141-67. [CrossRef]

Fanner, Deborah, and Christine Urquhart. 2008. Bibliotherapy for mental health service users Part 1: A systematic review. Health Information and Libraries Journal 25: 237-525. [CrossRef] [PubMed]

Garssen, Bert, Nicoline F. Uwland-Sikkema, and Anja Visser. 2014. How spirituality Helps Cancer Patients with the Adjustment to their Disease. Journal of Religion and Health 54: 1249-65. [CrossRef]

Gots, Jacob. 2016. Anxious? Depressed? Literate? Try bibliotherapy. Big Think. Available online: http://bigthink.com/ think-tank/anxious-depressed-literate-try-bibliotherapy (accessed on 20 January 2020).

Gregory, Kathrine E., and Judith A. Vessey. 2004. Bibliotherapy: A strategy to help students with bullying. Journal of School Nursing 20: 127-33. [CrossRef]

Gualano, M. R., F. Bert, M. Martorana, G. Voglino, V. Andriolo, R. Thomas, C. Gramaglia, P. Zeppegno, and R. Siliquini. 2017. The long-effects of bibliotherapy in depression treament. Systematic review of rendomized clinical trials. Clinical Psychology Review 58: 49-58. [CrossRef]

Horti, József, and Ágnes Riskó, eds. 2006. Onkopszichológia a gyakorlatban. Budapest: Medicina.

Josephson, Allan M. 2004. Formulation and treatment: Integrating religion and spirituality in clinical practice. Child and Adolescent Psychiatric Clinics 13: 71-84. [CrossRef]

Koenig, Harold D. 2008. Concerns about measuring "spirituality" in research. Journal of Nervous and Mental Disease 196: 349-55. [CrossRef] [PubMed]

Lazenby, Mark. 2018. Understanding and addressing the religious and spiritual needs of advanced cancer patients. Seminars in Oncology Nursing 34: 274-83. [CrossRef] [PubMed]

Maich, Kimberly, and Sharon Kean. 2004. Read two books and write me in the morning! Bibliotherapy for social emotional intervention in the inclusive classroom. Teaching Exceptional Children Plus 1: EJ966510.

Mailáth, Mónika, Réka Laczkóné Majer, Zsolt Horváth, and Gergely Sándor Szabó. 2017. A pszichés morbiditások korai felismerése a pszichoonkológiai ellátás során (Pszichoonkológiai szúrővizsgálat bevezetése Magyarországon I.). Magyar Onkológia 61: 276-83. [PubMed]

Malibiran, Ryan, Joseph D. Tariman, and Kim Amer. 2018. Bibliotherapy: Appraisal of evidence for patients diagnosed with cancer. Clinical Journal of Oncology Nursing 22: 377-80. [CrossRef] 
McCarty Hynes, Arlene, and Mary Hynes-Berry. 2012. Biblio/Poetry Therapy: The Interactive Process: A Handbook. St. Cloud: North Star.

McGrath, Alister A. 1999. Christian Spirituality. Oxford: Blackwell.

Menyhárt, Otília, János T. Fekete, and Balázs Győrffy. 2018. Demographic shift disproportionately increases cancer burden in an aging nation: Current and expected incidence and mortality in Hungary up to 2030. Clinical Epidemiology 10: 1093-108. [CrossRef]

Montgomery, Paul, and Kathryn Maunders. 2015. The effectiveness of creative bibliotherapy for internalizing, externalizing, and prosocial behaviors in children: A systematic review. Children $\&$ Youth Services Review 55: $37-47$.

Moreira-Almeida, Alexander, Harold D. Koenig, and Giancarlo Lucchetti. 2014. Clinical implications of spirituality to mental health: Review of evidence and practical guidelines. Revista Brasileira de Psiquiatria 36: 176-82. [CrossRef] [PubMed]

Popa, Dana, and Daniela Porumbu. 2017. Bibliotherapy in clinical context: An umbrella review. Bulletin of the Transilvania University of Brasov. Series VII: Social Sciences. Law 10: 165-74.

Riley, Barth B., Robert Perna, Denise G. Tate, Marty Forchheimer, Cheryl Anderson, and Gail Luera. 1998. Types of spiritual well-being among persons with chronic illness: Their relation to various forms of quality of life. Archives of Physical Medicine and Rehabilitation 79: 258-64. [CrossRef]

Seybold, Kevin S., and Peter C. Hill. 2001. The Role of Religion and Spirituality in Mental Health and Physical Health. Current Directions in Psychologic Science 10: 21-24. [CrossRef]

Surbone, Antonella, and Lea Baider. 2010. The spiritual dimension of cancer care. Critical Reviews in Oncology/Hematology 73: 228-35. [CrossRef] [PubMed]

Wachholtz, Amy B., and Kenneth I. Pargament. 2005. Is spirituality a critical ingredient of meditation? Comparing the effects of spiritual meditation, secular meditation, and relaxation on spiritual, psychological, cardiac, and pain outcomes. Journal of Behavioral Medicine 28: 369-84. [CrossRef] [PubMed]

Walsh, Froma. 2010. Spiritual diversity: Multifaith perspectives in family therapy. Family Process 49: $330-48$. [CrossRef] [PubMed]

Wills, Margaret. 2007. Connection, action, and hope: An invitation to reclaim the "spiritual" in health care. Journal of Religion and Health 46: 423-36. [CrossRef]

(C) 2020 by the authors. Licensee MDPI, Basel, Switzerland. This article is an open access article distributed under the terms and conditions of the Creative Commons Attribution (CC BY) license (http://creativecommons.org/licenses/by/4.0/). 